MSC 41A50

DOI: $10.14529 / \mathrm{mmp} 190412$

\title{
SYNTHESIS OF SURFACE H-POLARIZED CURRENTS ON AN UNCLOSED CYLINDRICAL SURFACE
}

\section{S.I. Eminov ${ }^{1}$, S.Yu. Petrova ${ }^{2}$}

${ }^{1}$ Yaroslav-the-Wise Novgorod State University, Veliky Novgorod, Russian Federation

${ }^{2}$ Sevastopol State University, Sevastopol, Russian Federation

E-mails: eminovsi@mail.ru, master@sevsu.energynet.ru

The article describes the inverse problem of diffraction of electromagnetic waves, finding surface $\mathrm{H}$-polarized currents on an unclosed cylindrical surface according to a given radiation pattern. The work is based on modelling an operator equation with a small parameter. The operator is represented as the sum of a positive-definite, continuously invertible operator and a compact positive operator. The positive-definite operator exactly coincides with the main operator of the corresponding direct problem of diffraction of electromagnetic waves. Due to this fact, the solution to the simulated equation satisfies the necessary boundary conditions. And this is the novelty and difference of the approach developed in this work from the methods known in the scientific literature. We develop a theory of an operator equation with a small parameter and a numerical method based on Chebyshev polynomials with weights that take into account the behavior at the boundary. The efficiency of the numerical method is shown.

Keywords: inverse diffraction problem; equation with a small parameter; positive definite operator; completely continuous operator; Hilbert space.

\section{History of the Problem}

For the first time, the problem of finding the currents that create a pre-set direction pattern was considered by Bakhrakh L.D., Kremenetsky S.D. in the monograph [1]. The connection between surface currents and the direction pattern for a cylindrical surface is described by the equation [2, p. 145]

$$
K u=f,
$$

where $K$ is the completely continuous integral operator that belongs to the space $L_{2}[-1,1]$. We do not give the form of the operator $K$, we only note that the core is an infinitely differentiable function of two variables.

The Hilbert space $L_{2}[-1,1]$ is represented as the direct sum of the closure of the image and the kernel conjugate:

$$
L_{2}[-1,1]=\overline{R(K)} \oplus N\left(K^{*}\right) .
$$

According to (2), the element $f$ is decomposed into the sum: $f=\bar{f}+f_{0}$. Three cases are possible:

1. $f_{0}=0$, the function $f \in R(K)$ is realizable;

2. $f_{0}=0$, the function $f \in \overline{R(K)}$ is approximable;

3. $f_{0} \neq 0$, the function $f \notin \overline{R(K)}$ is not approximable [3].

In order to determine the case in the considered situation and to find the minimum of the quadratic functional

$$
M(u)=\|K u-f\|^{2}
$$

on some set, the monograph [4] propose the general methods. 


\section{Statement of the Problem}

It is necessary to find a function with the given properties. And if the inverse problem of synthesis of surface currents on a cylindrical surface is solving, then it is necessary that the currents have the same properties as the currents in the direct problem. To this end, we involve the equation of the direct problem considered in [5]:

$$
\begin{gathered}
(A u)(\tau)+(K u)(\tau) \equiv \frac{1}{\pi} \frac{\partial}{\partial \tau} \int_{-1}^{1} u(t) \frac{\partial}{\partial t} \ln \frac{1}{|\tau-t|} d t+ \\
+\int_{-1}^{1} K(\tau, t) u(t) d t=f(\tau),-1 \leq \tau \leq 1
\end{gathered}
$$

where $A$ is a positive definite operator.

The carrier of the properties of surface currents is the operator $A$. The operator $K: H_{A} \rightarrow L_{2}[-1,1]$, where $H_{A}$ is the energy space of a positive definite operator $A$. Recall that the scalar multiplication and the norm in $H_{A}$ are determined by the formulas, considered in [6]:

$$
[u, v]=(A u, v),[u]^{2}=(A u, u) .
$$

This paper essentially uses the following fundamental result obtained in the paper [7].

Theorem 1. The operator $A^{-1}$ is defined on the dense set $L_{2}[-1,1]$ and is completely continuous. The operator is defined on in and is completely continuous.

\section{Theoretical Study of Approximmability}

The problem of finding the minimum of the functional (3) is unstable [4]; therefore, we introduce into consideration the quadratic functional with a small parameter

$$
N(u)=\alpha(A u, u)+\|K u-f\|^{2}, u \in D(A),
$$

where $D(A)$ is the domain of the operator $A, \alpha$ is a small parameter. The Euler equation for the functional (4) has the form

$$
\alpha A u+K^{*} K u=K^{*} f .
$$

As shown in the paper [8, 10], the minimum of functional (4) is achieved precisely on solutions to equation (5). Equation of the direct diffraction problem (4), equation with a small parameter (5), and the equation of the inverse problem, have the same structure. Apply the operator $A^{-1}$ to equation (5), and obtain the equivalent equation

$$
\alpha u+A^{-1} K^{*} K u=A^{-1} K^{*} f .
$$

Further, each solution to equation (5) is also a solution to equation (6). A solution to equation (6) may not belong to the domain of definition of the operator $A$. Such solutions are called generalized solutions. With this proviso, equations (5) and (6) are equivalent.

Equation (5) is considered in the Hilbert space $H_{A}$. As a consequence of Theorem 1, we obtain that the operator $T=A^{-1} K^{*} K$ is completely continuous in $H_{A}$. In addition, the operator $T$ is positive: $\left[A^{-1} K^{*} K u, u\right]=\left(K^{*} K u, u\right)=(K u, K u) \geq 0$ and therefore selfadjoint $\left[9\right.$, p. 352]. In the Hilbert space $H_{A}$, a self-adjoint completely continuous operator has a complete system of orthonormal eigenfunctions:

$$
\begin{gathered}
A^{-1} K^{*} K \psi_{n}=\lambda_{n}^{2} \psi_{n}, n=1,2, \ldots, \lambda_{n}^{2}>0, \\
A^{-1} K^{*} K \psi_{m}^{\prime}=0, m=1,2, \ldots
\end{gathered}
$$


Theorem 2. The system of functions $M=\left\{\psi_{n}, n=1,2, ..\right\} \cup\left\{/ \psi_{m}^{\prime}, m=1,2, \ldots\right\}$ is also complete in the space $L_{2}[-1,1]$.

Proof. Let $f \in L_{2}[-1,1]$ be an element, which is orthogonal to all functions from the set $M:\left(f, \psi_{n}\right)=0,\left(f, / \psi_{m}^{\prime}\right)=0$. Consider the preimage $A^{-1} f \in H_{A}$. We have $\left[A^{-1} f, \psi_{n}\right]=$ $\left(A A^{-1} f, \psi_{n}\right)=\left(f, \psi_{n}\right)=0$. By the same reason, $\left[A^{-1} f, \psi_{m}^{\prime}\right]=0$. Hence, an element $A^{-1} f$ is orthogonal to $H_{A}$ a complete set, i.e. $A^{-1} f=0$. Then $f=0$.

From this theorem we derive following statement

Theorem 3. 1) The system of functions $K \psi_{n}, n=1,2, \ldots$, is complete and orthogonal in the space $\overline{R(K)} \subset L_{2}[-1,1]$. 2) Equality is fair. These equalities are correct $K / \psi_{m}^{\prime}=$ $0, m=1,2, \ldots$.

Theorem 4. To implement the function $f$, i.e. $K u \in R(K)$ necessary to satisfy the inequality

$$
\sum_{n}\left|\frac{\left(f, K \psi_{n}\right)}{\lambda_{n}^{2}}\right|^{2}<+\infty
$$

and if $K u \in \overline{R(K)}$, then inequality (9) is also a sufficient condition.

Proof. If $f$ is implemented, then there is such an element

$$
u=\sum_{n}\left(u, \psi_{n}\right) \psi_{n}+\sum_{m}\left(u, \psi_{m}^{\prime}\right) \psi_{m}^{\prime}
$$

that $f=K u$. Then

$$
\frac{\left(f, K \psi_{n}\right)}{\lambda_{n}^{2}}=\frac{\left(K u, K \psi_{n}\right)}{\lambda_{n}^{2}}=\left(u, \psi_{n}\right)
$$

From here, with considering the Bessel inequality in the Hilbert space, we obtain (9). We prove the sufficiency. If inequality (9) realized, then the formula

$$
u=\sum_{n} \frac{\left(f, K \psi_{n}\right)}{\lambda_{n}^{2}} \psi_{n}
$$

defines some element of the space $H_{A}$. Since the operator $K$ is continuous, the system $K \psi_{n}, n=1,2, \ldots$ is complete in the space $\overline{R(K)} \subset L_{2}[-1,1]$, and the condition $f=\bar{f}$ holds, we have

$$
\|f-K u\|^{2}=\|\bar{f}-K u\|^{2}=\lim _{n \rightarrow+\infty}\left\|\bar{f}-\sum_{k=1}^{n} \frac{\left(\bar{f}, K \psi_{k}\right)}{\lambda_{k}^{2}} K \psi_{k}\right\|^{2}=0 .
$$

Let us turn to the Euler equation (6). Using the proper decomposition (10) and Theorem 3, we find a solution to the equation with a small parameter:

$$
u_{\alpha}=\sum_{n} \frac{\left(f, K \psi_{n}\right)}{\alpha+\lambda_{n}^{2}} \psi_{n}
$$


By dint of (11), we find the norm in the energy space and the residual:

$$
\begin{gathered}
\xi(\alpha)=\left[u_{\alpha}\right]^{2}=\sum_{n}\left|\frac{\left(f, K \psi_{n}\right)}{\alpha+\lambda_{n}^{2}}\right|^{2}, \\
\chi(\alpha)=\left\|K u_{\alpha}-f\right\|^{2}=\sum_{n}\left|\frac{\alpha}{\alpha+\lambda_{n}^{2}}\right|^{2}\left|\left(f, K \psi_{n}\right)\right|+\left\|f_{0}\right\|^{2} .
\end{gathered}
$$

From formulas (12) and (13) it follows that the norm function $\xi(\alpha)$ decreases monotonically, and the residual $\chi(\alpha)$ increases monotonically. If $\lim \chi(\alpha)=0$ and $\lim \xi(\alpha)<+\infty$ with $\alpha \rightarrow 0+$ then the function is realizable; if $\lim \chi(\alpha)=0$ and $\lim \xi(\alpha)=+\infty$, then the function is not realizable, but is approximable; finally, if $\lim \chi(\alpha)>0$, then the function is not approximable. The following theorem is a consequence of Theorem 4 .

Theorem 5. If $0<r_{0}^{2}<\lim \xi(\alpha)$, then the functional (2) reaches a minimum on the set $[u]^{2} \leq r_{0}^{2}$, at that at a single point.

\section{Example of Numerical Algorithm}

We do not know the eigenfunctions $\psi_{n} / \psi_{m}^{\prime}$, therefore, to solve the Euler equation (5), we use functions that are used to solve the direct problem [7], namely, the system of functions

$$
\varphi_{n}(\tau)=\sqrt{\frac{2}{\pi n}} \sin [n \arccos (\tau)]=\sqrt{\frac{2}{\pi n}} \sqrt{1-\tau^{2}} U_{n}(\tau), n=1,2,3, \ldots,
$$

here $(\cdot, \cdot)$ means the scalar product in $L_{2}[-1,1]$, and $U(\tau)$ is the Chebyshev polynomials of the second kind $U_{1}(\tau)=1, U_{2}(\tau)=2 \tau, U_{3}(\tau)=4 \tau^{2}-1, \ldots$

This one is full and orthonormal

$$
\left[\varphi_{n}, \varphi_{m}\right]=\left(A \varphi_{n}, \varphi_{m}\right)=\left\{\begin{array}{l}
1, m=n \\
0, m \neq n
\end{array}\right.
$$

then it is an orthonormal basis of space $H_{A}$ [7].

In addition, the basis functions $\varphi_{n}(\tau)$ satisfy the Meixner condition on the edge: the basis functions tend to zero according to the law $\varphi_{n}(\tau)=$ const $\cdot \sqrt{1-\tau}$ when $\tau \rightarrow 1$ (the radiation point approaches the edge). And the basis functions tend to zero as $\varphi_{n}(\tau)=$ const $\cdot \sqrt{1+\tau}$ when $\tau \rightarrow-1$ (the point of radiation approaches the other edge).

An approximate solution to equation (6) is countuened in the form

$$
u(\tau)=\sum_{n=1}^{N} c_{n} \varphi_{n}(\tau) .
$$

We substitute (16) into (5) and multiply by basis functions $\varphi_{1}, \varphi_{2}, \ldots, \varphi_{N}$ scalarly in the space $H_{A}$. Considering equality (15), we obtain a system of linear algebraic equations

$$
\alpha c_{n}+\sum_{m=1}^{N} c_{m} K_{m n}=f_{n}, n=1,2,, \ldots, N .
$$

where $K_{m n}=\left(K^{*} K \varphi_{m}, \varphi_{n}\right)=\left(K \varphi_{m}, K \varphi_{n}\right), f_{n}=\left(K^{*} f, \varphi_{n}\right)=\left(f, K \varphi_{n},\right)$. 
After solving system (17), we find the approximate value of the norm and the residual:

$$
\left[u_{\alpha}\right]=\sqrt{\sum_{n=1}^{N}\left|c_{n}\right|^{2}},\left\|K u_{\alpha}-f\right\|=\sqrt{\int_{-1}^{1}\left\|\left(K u_{\alpha}\right)(\tau)-f(\tau)\right\|^{2} d \tau} .
$$

In conclusion, we consider a model example. After changing the variable, the connection between the surface currents and the radiation pattern for the band, is given by the following integral completely continuous operator:

$$
f(\tau)=K u=\int_{-1}^{1} \exp (i k a \tau t) u(t) d t
$$

where $k=2 \pi / \lambda$ is a propagation number, $\lambda$ is a wavelength, in calculations it is usually specified like $a / \lambda$ the ratio of the half-width of the band to the wavelength. Table illustrates the convergence of the Galerkin method for small values of the parameter $\alpha$. The results obtained with $N=10$ and $N=20$ completely coincided, which indicates a good convergence of this numerical method.

\section{Table}

Internal convergence of the numerical method

\begin{tabular}{|c|c|c|c|c|}
\hline$N$ & \multicolumn{2}{|c|}{$\frac{a}{\lambda}=0,5, \alpha=0,001$} & \multicolumn{2}{c|}{$\frac{a}{\lambda}=0,5, \alpha=0,000001$} \\
\hline & {$\left[u_{\alpha}\right]$} & $\left\|K u_{\alpha}-f\right\|$ & {$\left[u_{\alpha}\right]$} & $\left\|K u_{\alpha}-f\right\|$ \\
\hline 1 & 0,8014824 & 0,07117072 & 0,8019675 & 0,07116798 \\
\hline 5 & 1,034875 & 0,04108093 & 3,527968 & 0,002271569 \\
\hline 10 & 1,034875 & 0,0408093 & 3,527968 & 0,00271566 \\
\hline 20 & 1,034875 & 0,0408093 & 3,527968 & 0,00271566 \\
\hline
\end{tabular}

\section{Summary}

Therefore, the following results were obtained.

1) In the energy space $H_{A}$ of a positive definite self-adjoint operator it is proved that the Euler equation has a unique generalized or classical solution the direct diffraction problem on an unclosed cylindrical surface.

2) We study the properties of the solution $u_{\alpha}$ to the Euler equation. We obtain explicit formulas for the norm and the residual, from which it follows that the norm is a decreasing function of the parameter $\alpha$, and the residual is a monotonically increasing function.

3 ) It is proved that the problem of finding the minimum of a residual has a unique solution on a set bounded in norm set in the energy space.

4) We obtain the formulas for finding the functionals of the norm and residual after solving the Euler integro-differential equation with a small parameter.

\section{References}

1. Bakhrakh L.D., Kremenetskiy S.D. Sintez izluchayushchikh sistem. Teoriya i metody rascheta [Synthesis of Radiating Systems (Theory and Methods of Calculation)]. Moscow, Sovetskoe radio, 1974. (in Russian) 
2. Zakharov E.V., Pimenov Yu.V. Chislennyy analiz difraktsii radiovoln [Numerical Analysis of Radio Wave Diffraction]. Moscow, Radio i svyaz', 1982. (in Russian)

3. Katsenelenbaum B.Z. Problemy approksimiruemosti elektromagnitnogo polya [Electromagnetic Field Approximability Problems]. Moscow, Nauka, 1996. (in Russian)

4. Ivanov V.K., Vasin V.V.,Tanana V.P. Teoriya lineynykh nekorrektnykh zadach $i$ ee prilozheniya [The Theory of Linear Ill-Posed Problems and Its Applications]. Moscow, Nauka, 1978. (in Russian)

5. Sochilin A.V., Eminova V.S., Eminov I.S. [The Galerkin Method in the Problem of Diffraction of the H-Polarization on a Cylindrical Surface]. Non-linear World, 2014, no. 6, pp. 26-31. (in Russian)

6. Mikhlin S.G. Lineynye uravneniya $v$ chastnykh proizvodnykh [Linear Partial Differential Equations]. Moscow, Nauka, 1977.

7. Eminova V.S., Eminov S.I. [Justification of the Galerkin Method for Hypersingular Equations]. Journal of Computational Mathematics and Mathematical Physics, 2016, vol. 56, no. 3, pp. 432-440. (in Russian)

8. Sakhnovich L.A. [Equations with a Difference Kernel on a Finite Interval]. Russian Mathematical Surveys, 1980, vol. 35, no. 4, pp. 69-129. (in Russian)

9. Rudin W. Functional Analysis. N.Y., McGRAW-Hill Book Company, 1973.

10. Sukacheva T.G., Matveeva O.P. [Taylor Problem for the Zero-Order Model of an Incompressible Viscoelastic Fluid], Differential Equations, 2015, vol. 51, no. 6, pp. 783-791.

Received February 1, 2019

УДК $621.396+517.9$

DOI: $10.14529 / \mathrm{mmp} 190412$

\title{
СИНТЕЗ ПОВЕРХНОСТНЫХ Н-ПОЛЯРИЗОВАННЫХ ТОКОВ НА НЕЗАМКНУТОЙ ЦИЛИНДРИЧЕСКОЙ ПОВЕРХНОСТИ
}

\author{
С.И. Эминов ${ }^{1}$, С.Ю. Петрова ${ }^{2}$ \\ ${ }^{1}$ Новгородский государственный университет им. Ярослава Мудрого, \\ г. Великий Новгород, Российская Федерация \\ ${ }^{2}$ Севастопольский государственный университет, г. Севастополь, \\ Российская Федерация
}

Работа посвящена обратным задачам дифракции электромагнитных волн, нахождению поверхностных Н-поляризованных токов на незамкнутой цилиндрической поверхности по заданной диаграмме направленности. В основе работы лежит моделирование операторного уравнения с малым параметром. Оператор представлен в виде суммы положительно-определенного, непрерывно-обратимого оператора и компактного положительного оператора. Положительно-определенный оператор в точности совпадает с главным оператором соответствующей прямой задачи дифракции электромагнитных волн. Благодаря этому факту, решение смоделированного уравнения удовлетворяет нужным граничным условиям. И в этом новизна и отличие развитого в данной работе подхода от известных в научной литературе методов. В работе авторами разработана теория операторного уравнения с малым параметром и численный метод на основе полиномов Чебышева с весом, учитывающим поведение на границе. Показана эффективность численного метода.

Ключевые слова: обратная задача дифракиии; уравнение с малым параметром; положительно-определенный оператор; вполне непрерывный оператор; гильбертово пространство. \& Computer Software (Bulletin SUSU MMCS), 2019, vol. 12, no. 4, pp. 135-141 


\section{Литература}

1. Бахрах, Л.Д. Синтез излучающих систем (теория и методы расчета) / Л.Д. Бахрах, С.Д. Кременецкий. - М.: Советское радио, 1974.

2. Захаров, Е.В. Численный анализ дифракции радиоволн / Е.В. Захаров, Ю.В. Пименов. М.: Радио и связь, 1982.

3. Каценеленбаум, Б.З. Проблемы аппроксимируемости электромагнитного поля / Б.З. Каценеленбаум. - М: ФИЗМАТЛИТ, 1996.

4. Иванов, В.К. Теория линейных некорректных задач и ее приложения / В.К. Иванов, В.В. Васин, В.П. Танана. - М.: Наука, 1978.

5. Сочилин, А.В. Метод Галеркина в задаче дифракции Н-поляризации на цилиндрической поверхности / А.В. Сочилин, В.С. Эминова, И.С. Эминов // Нелинейный мир. - 2014. № $6 .-$ C. $26-31$.

6. Михлин, С.Г. Линейные уравнения в частных производных / С.Г. Михлин. - М.: Наука, 1977.

7. Эминова, В.С. Обоснование метода Галеркина для гиперсингулярных уравнений / В.С. Эминова, С.И. Эминов // Журнал вычислительной математики и математической физики. - 2016. -Т. 56, № 3. - С. 432-440.

8. Сахнович, Л.А. Уравнения с разностным ядром на конечном отрезке / Л.А. Сахнович // Успехи математических наук. - 1980. - Т. 35, № 4. - С. 69-129.

9. Rudin, W. Functional Analysis / W. Rudin. - New York: McGRAW-Hill Book Company, 1973.

10. Сукачева, Т.Г. Задача Тейлора для модели несжимаемой вязкоупругой жидкости нулевого порядка / Т.Г. Сукачева, О.П. Матвеева // Дифференциальные уравнения. 2015. - T. 51, № 6. - C. 783-791.

Стефан Ильич Эминов, доктор физико-математических наук, профессор, директор, Институт электронных и информационных систем, Новгородский государственный университет им. Ярослава Мудрого (г. Великий Новгород, Российская Федерация), eminovsi@mail.ru.

Светлана Юрьевна Петрова, кандидат технических наук, доцент, заведующий кафедрой «Интеллектуальные сети энергоснабжения», Севастопольский государственный университет, (г. Севастополь, Российская Федерация), master@sevsu.energynet.ru.

Поступила в редакиию 1 февраля 2019 г. 